\title{
The Christian church's role in the escalating mob justice system in our black townships - An African pastoral view
}

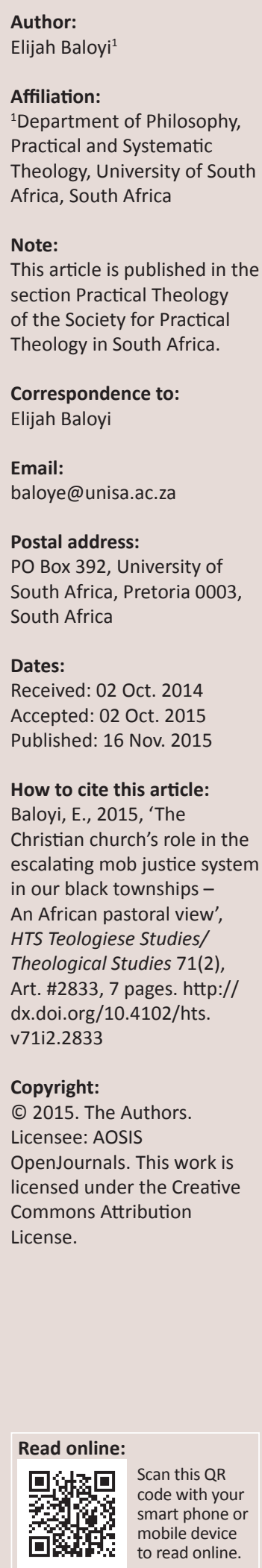

Among the crimes in the South African black townships, mob justice has become a growing concern. Some questions that need to be asked are: Is our police force doing enough to protect the ordinary citizens of this country? If the situation continues, will all suspects be killed in the same manner or will there be a solution to change the situation? What is the impact of mob justice on the families of the victims and the witnesses of the brutal acts? How long are we going to live as a traumatised nation as a result of these violent acts? Is there any hope that our nation will ever have the peace it deserves in the context of democracy? This article intends to investigate the impact of the mob justice system and find out what the role of the Christian church should be in the midst of this escalating violence. This study aims to unveil the negative impact of mob justice on the lives of many township South Africans and giving pastoral-biblical suggestions of the church's role in the elimination of this kind of brutality.

\section{Introduction}

The prevalence of mob justice in our black townships has not only been one of the issues that undermines $u b u n t u$, but it has also become a growing concern for many people in South Africa. The article entitled, 'Suspects killed in front of cops' reported how two males who used to dress as females in order to confuse and rob people were hunted down, severely beaten and stoned to death in Mashishimale, outside Phalaborwa in Limpopo. The mob was so angry that the police could not stop them. They went on to kill the two people who were suspected of killing a 57year old man and robbing many people of their belongings (AENS 2014:4). If people continue with brutality in front of the police it indicates that their anger is uncontrollable, and such anger is a revelation of a traumatised nation. My concern is that if the police fail to contain and control the anger of people, what kind of safety is the nation left with? I always felt safe in the presence of police officers. Just as I am still worried about our safety, another incident took place in Khayelitsha where an alleged cellphone robber was found dead in the street after the residents showed him no mercy and killed him. He initially managed to escape their beating but, as they were not satisfied with this degree of retaliation, they chased him, caught him and stabbed him to death (Lali 2014:4). Sibiya (2014:4) reported another incident in which 'gatvol residents' were quoted as saying: 'He is going to sit here until we get our money.' This was after a suspected car parts thief was caught by residents in Tembisa, tied up with a stolen crankshaft, and left in the sun on a hot day as punishment. The question is, should we be allowed to punish those who have wronged us, or should we hand them over to the police for justice to take place? The picture of a man with torn trousers who was whisked out of a spaza shop in Odi, near Mabopane in Tshwane North, by security guards after he was kicked and 'sjambokked' by angry residents when caught trying to steal airtime. Although I am not supporting or protecting evil doers who rape, kidnap, break and steal, I am still worried that this has lead people to treat each other like animals.

What makes it even more difficult to believe is that this kind of violence is taking place in a country whose democratic constitution respects, regards and upholds human life highly. That is why until today, South Africa, according to Ncayiyana, believes that:

Termination of a person's life is unlawful, even if the motive of such conduct is to end the person's unbearable suffering, even where the suffering person has expressed a wish to die or has even begged to be killed. (Ncayiyana 2012:1)

These few incidents inform me that besides the fact that we are fast becoming a sick society, something is wrong with the people's minds, to the extent of becoming a hostile nation. This makes a study of this kind not only relevant, but even more contextual. 


\section{The relevance and method of study}

Many lives have been lost and others are still being lost resulting from the practice of mob justice in South Africa. Practical theology can no longer afford to turn a blind eye in addressing some of the issues relating to the reduction of mob society, which is fast turning this nation violent. People are killed because they are suspected of crime. This causes families to lose their breadwinners who would have provided for them and paid for their education. The lives of family members and friends of the victims are traumatised by mob justice, hence it is the people's lives that this study is concerned with. The death of relatives, particularly in the context of mob justice, continues to traumatise many people and families. It is God's children who are being traumatised by these violent killings. More than just receiving attention, theology that speaks to the lives of people must address and come up with possible suggestions that will uproot any system that violates human life and human rights. Regardless of the offence that perpetrators commit against others, it warrants that theological research should examine such brutal deaths and punishments on residents of these places. One of the concerns is whether or not we still see the image of God (imago Dei) within the perpetrators who are beaten, kicked, burnt or killed. As a practical theologian, I see it as imperative that although justice must be preserved, the safety and the lives of people must also be considered. Therefore, the research is not only aimed at condemning the mob justice system, but it will also suggest some pastoral ways in which the church can assist in educating our citizens about the importance of human life, whilst also looking at possible remedies to avoid or reduce the crime that is turning our beautiful nation into a violent one. Violence and mob justice might be experienced in other countries, but this study focuses on South Africa, particularly the black townships in which these practices are fast becoming common.

\section{Background and the possible causes of the practice}

According to Cook (2013:4) the growing crime rate in South Africa, in which people are assaulted, raped and even killed, is so alarming that people are beginning to defend themselves, and mob justice is one of the ways for them to fight back. Anthony Minnaar (2001:1) uses the concept 'vigilantism' to refer to the practice in which the community uses violence either by 'necklacing' or stoning to death those who rob, rape and commit other crimes in their areas. Many South Africans remain exposed to violent acts, including different forms of vigilantism. My personal observation is that the violent reactions and strivings that occurred during and against apartheid became a norm which continues to surface whenever frustrating situations arise in our communities. Frantz Fanon, who wrote much about violence and postcolonialism (in the Algerian context), explored how the colonial ideologies have been hammered into the native minds to entrench self-hatred, inferiority and aggressiveness that can still be seen today. I am in full agreement with Fanon
(1963:28) who argues that the naked truth of decolonisation evoked bloodstains, bullets and violent murders that we experience in our lives. The author is of the opinion that not much has been accomplished to undo or arrest what the colonial mind has influenced to produce violent nations and people. Fanon (1963:29) is correct to assert that the more violence it took for the natives to dislodge colonisation and unjust practices, the more a violent attitude became part of the native's life. It is in this context, where the political inequalities of the past in South Africa connect with our present calamities and challenges, in which there is still a long way to go for real freedom to manifest in the lives of many people in South Africa. Reports of such criminal acts against suspects have been increasing in weekly reports and there is a likelihood that this will be a growing trend if nothing is done to stop it (Brodie 2013:1). The assembling of a mob to take action varies from one situation to the other, but one of the ways that this occurs is with the use of the so-called vimba (catch/stop) and 'whistle blowing' in some townships when someone experiences discomfort in their homes or elsewhere. This kind of invitation has received much criticism from participants in Madienyane's (2013) research because they claim that some people whistle or scream for many reasons. It is frightening to touch a person even when just walking in shopping complexes because if the person you have touched decides to scream, claiming that you searched or tried to take something from them, that alone can cost one one's life.

There is enough evidence (e.g. AENS 2014; Brodie 2013; Goldbaum 2014) to support the fact that many lives in this country have been lost resulting from the mob justice system. Normally, one of the causes of this is because people have lost patience and faith in the justice system of the country, hence they made the decision to take the law into their own hands. Crime in South Africa is growing at an alarming rate, to the extent that victims think that they are left with no choice other than to fight for themselves. The element of ubuntu, 'I am because we are' is abused by some Africans who conspire to commit crimes. This is the ugly or shadow side of ubuntu discourse and philosophy. A certain Angelina Maholwana expressed that she felt justice had been achieved after seeing the dead bodies of two young men who broke into her house and killed her son and attempted to rape her in Port Elizabeth (Jazzie 2014:1). Angelina went on to say: 'I know that killing these boys will not bring back my son, but I sleep better now, knowing those boys will not hurt anyone again.' The lady seemed content with what mob justice had achieved in retaliation for the killing of her son. This is an unfortunate situation which often results from frustrations, and leads to one wrong paying for another, which is not acceptable at all.

In another incident an old woman (Vinolia Sesing) narrowly survived death when she was severely beaten and thrown out of the community. This old woman was suspected of having turned a villager into a zombie in Mokasa village near Taung, North West (Maje 2014:5). Incidents of this nature are becoming common amongst black people. 
According to SAPA (2013:1), many young people claim that 'useless police' are the cause of the vigilantism because they are not doing what is expected of them to reduce crime. A Pondering Panda spokesperson, Shirley Wakefield, said in a SAPA report:

It's clear that young people feel the justice system in South Africa is failing their communities when it comes to tackling crime, and that vigilantism and mob justice are a valid means of punishing criminals. (SAPA 2013:1)

According to her, 'the study revealed that most young people felt vigilante justice was socially acceptable'. Saba (2013) argues that anger and resentment are the two main causes that result in mob justice. Mathye (2016:18) also argues that a survey has showed that three out of ten people fear the police and that the police force is losing the public's trust.

It is important to note that one of the main reasons why people take the law into their own hands by eliminating those who rob, steal and rape their loved ones is because they no longer have confidence in the police. About this Tshehla (2014:10) explained: 'Government is quick to discourage people from taking the law into their own hands but fails to punish lawbreaking officers.' This argument is connected with the claim that the police themselves are often accused of misconduct, criminality, unlawfulness and brutality. An example which was used to strengthen this claim was that of the Marikana killings, in which the hearing concerning it continues to take more time to complete whilst the widows of the killed mineworkers are left without breadwinners. A reporter went on to indicate that almost 9000 cases of crimes committed by SAPS members were reported, which makes the safety of the law abiding citizens uncertain, hence the escalation of mob justice (Tshehla 2014:10). The frustration with the police was also articulated by a particular woman, quoted by Mabena (2014:1), during the time when the Slovo Park residents beat a man until one of his eyes was ripped out. These residents stated: 'We are tired of this boy's behaviour. He steals from us but when we take him to the police he gets released the following day.' This is the perception of most citizens about the justice system, which promotes uncertainty and frustration. In another incident, the Ethekwini Municipality confirmed the arrest of the offduty police officer who was connected to the hijacking of a business man in Umhlanga. The businessman was firstly forced to withdraw cash by a gang that included this police officer before they hijacked him (Sihle 2014:5). On the other hand, seven police officers are facing charges in the Belville High Court, Cape Town, for assaulting a Somali community leader (Writer 2014:6). A 50-year old woman, Joyce Matsiu from Mokopane also claims that the Mahwelereng police refused to help her open a case of assault against her policeman-brother, who hit her with the back of his gun after beating her with a knife. She explained that they told her that they would not open a case because her brother is a member of that police station. This forced her to open the case in Atteridgville, Pretoria (Mohale 2014:17). These few police-related incidents not only show how corrupt some of our police officers are, but they also make it difficult for ordinary people to trust the police to protect their lives and their belongings. This creates further doubts about our justice system, hence people think they have to protect themselves instead of waiting for the judiciary system in which they have lost faith. This is how the frustrations of the community give birth to what we call mob justice. This is exactly how one resident felt after the mob burnt down the house of three brothers who had terrorised the community of Slovoville (West of Johannesburg) by stealing from them. The resident commented:

What is disturbing is that after we lay charges with the police, you see them on the streets again within a few days. If criminals keep getting bust and are out within days, where do we turn? (Mogotsi 2014:5)

According to Hamber and Lewis (1997:1) the mob justice system appears quicker and more effective as it restores the people's lack of faith in the justice system.

\section{The impact of the practice on the entire community}

A popular radio host was quoted by York (2014), who was lamenting:

I worry about the children in those communities. They are being taught the language of blood and death from an early age. We ought to worry about the impact of more brutality on an already brutalised people. (p. 2)

Children and some adults who watch this kind of brutal killing are exposed not only to blood and death, but also to the violence that takes place during the killings. That already is equal to breeding a family, a community and a nation that will not fear to shed human blood. My opinion is that the more our children are exposed to the violence that is confined within mob justice, as we perceive it in our townships, the more we breed the next generation of people who will have less or no respect for human life. It is difficult to imagine that, in some instances, it is teenagers and other young people who are at the forefront of the necklacing and burning of human bodies. It is both inhumane and unnatural to see human bodies being dragged through the streets and finally burnt or publicly killed.

\section{Some innocent lives are lost}

I am using the term 'innocent' deliberately because the South African law indicates that no one should be sentenced until proven guilty. There are many instances in which people have been burnt and even killed before there was enough evidence of their guilt. Siyavuya (2014:1) reported a painful incident in which a 17-year old boy, who was in Grade 6, was killed when he was beaten after being accused of stealing a cellphone, which was not in his possession. The boy's mother said after the killing: 'They did not find a cellphone in his possession.' This is one of the reasons why mob justice should be condemned because unfair judgements are made 
without ensuring that the offence has been committed. It is problematic for the family of the boy to lose him because of being wrongfully accused of theft. This injustice often breeds the spirit of revenge and, hence, the escalation of crime and more violent killings. Bearak (2011) in his article, 'Watching the murder of an innocent man' indicates how the mob justice system can sometimes deal with the wrong person. An innocent man was killed in Diepsloot. This is one example out of many in which the system proved to be inaccurate. It is a system that depends on what people say without thorough investigation. People who want to deal with their enemies can also spread false rumours about someone's criminal activity, knowing that the mob will deal with that person. Even though this study does not deal with witchcraft, both it and mob justice use the same source to uncover information - the local people who must claim that someone has wronged them. This argument finds support from Hund's (2000) article 'Witchcraft and accusations of witchcraft in South Africa'. The concept 'accusation' indicates clearly that there is no evidence about the event, but simply accusations that are mostly entertained by a subjective mind. Few respondents to Madienyane's (2013) research agreed that even if the victim turned out to be a mistaken target, the community would attempt to blame the victim for something in order to justify their actions. This testifies to the possibilities and probabilities of guiltless people being killed.

\section{Traumatic experiences}

It is clear that looking at a body which was burnt or killed by a mob, or watching it happen, is traumatising on its own. Besides the status of the victim in his own family (breadwinner, father or whatever), the fact that unexpected death took their loved one has its own unintended effects on the family's health, and psychological well-being. South Africa is already a traumatised nation because of the escalating crime and other calamities, but mob justice adds to the pain of the families and the community. The country already deals with pain over the issues related to street children, prostitution and so forth. Thus, these children will have to look for ways to survive. The direction they take to survive, whether good or bad, will only be determined by their immediate pain and suffering.

According to Goldbaum (2014:6) there are various side effects of child-related violence. The Alpine Primary School realised the various side effects because they were working with a Trauma Centre in Woodstock, which helps children who are traumatised by violence. Stavrou (2011), a former researcher at the Centre for Study of Violence and Reconciliation conducted a study in which she listed a few effects of violence:

- Emotional changes characterised by numbing, powerlessness, extreme vulnerability and a feeling of a lack of safety. Anxiety, irritability and restlessness also become part of this.

- The evidence of difficulty in sleeping resulting from nightmares about the attacks.
- Difficulty in thinking disables one's concentration as well as one's ability to remember properly, meaning that children in such environments cannot do well in their studies.

- Social isolation in which children will normally not want to socialise and will usually be aggressive.

- Headaches and stomach-aches also accompanied by refusal to eat and a lack of appetite.

These factors summarise amongst other things the existence of post-traumatic stress disorder (PTSD). That is why there is a need for pastoral caregivers and psychologists to work very hard alongside the community after these violent attacks to uproot these effects and ensure the right frame of mind.

\section{Instilling fear, resulting in a hopeless situation}

Many people are becoming hopeless not because of our democracy, but because of the violence that is taking their loved ones unjustly, whilst perpetrators are not harshly sentenced. I understand that there might be a temptation for revenge in these cases, but my argument is that two wrongs never equal one right. It has been read many times that we have become a fast growing violent nation with a lack of the desired respect for human life. For instance, if a person is killed for either owning or stealing a cellphone, at whatever price, then this is a clear indication that something has gone wrong in peoples' minds about the importance of life. Without attaching any price to a cellphone, which may be expensive or cheap, the issue is that its price does not equal the worth of a human life and can be replaced. Human life is priceless and cannot be compared to a cellphone, nor is it replaceable. There is truth in Shabangu's (2011:1) argument that because 'citizens are far more afraid of violence that threatens their lives, there is therefore an equally urgent need to develop interventions to reduce violence in general'. People, particularly in the former black townships of South Africa, are living in fear because of this kind of violence.

Madienyane (2013:58) indicates that the most common expressions made by people are fear of the security forces and of future attacks, particularly on a home in which children live. Some victims who are killed leave their siblings and families without bread-winners, hence a hopeless situation begins creeping into the lives of the bereaved and deserted families. Some of the 'street kids' and other homeless people are in that particular situation because people who used to provide food and shelter for them have been killed by mob justice. My concern is that we are adding more problems by creating more orphans and poverty than there was initially. These people find themselves uneducated and unable to look for employment because no one is taking care of them as the people who were taking responsibility for them, are dead. Although this is not a focus of this study, it still links to the issue, that it continues to be difficult to deal with escalating poverty in South Africa. This poverty breeds another generation that perpetuates violence and the circle of violence and poverty continues. 


\section{The role of the Christian church The family of the victims}

Although the family of a victim has no power to do anything about the victimisation and death of their loved one, they will continue to expect that justice will be achieved by dealing with the perpetrators. The family also becomes more devastated when authorities make the decision about when to release the body of their loved one for burial, in accordance with their customs and wishes. Such delays and post-mortem results further add to the trauma the family is already suffering. This has its own emotional side effects. It is during these trying times that the church must journey with the family, through its pastoral services. Prayers, counselling, motivation and encouragement help to strengthen the family. Even after the burial, the fact that they have to face the reality of hearing if the criminal has been found is also a reality to be faced with mixed emotions. Let it also be understood that when death strikes through sickness in an African family, much uncertainty engulfs the family. It is even worse if death is as a result of murder. Therefore, the trauma that the whole family goes through when their loved one has been killed is more painful than when they simply die from natural causes. This is what Casey (2011) calls the long-term effects of negative bereavement. It is from this perspective that some families, resulting from the unintended challenges they face, may decide that revenge can help to ease their pain. The lack of intervention during these trying times can add to the violence instead of reducing it.

Alongside the devastating grief, there is now substantial evidence that individuals, bereaved through homicide, are likely to experience trauma. A traumatic incident is defined as a specific event 'which is beyond normal experience' (Kirsti \& Dyer 2005:1). Traumatic stress is a normal human reaction in these circumstances. However, when the symptoms of traumatic stress become very severe, cluster together or persist over longer periods, an anxiety disorder, known as post-traumatic stress disorder (PTSD) can develop. This clearly indicates that the family of the victim needs the church to offer pastoral counselling in their bereavement. Human suffering as well as death has always resulted in unexpected outcomes that need counselling and the church must always ready itself for these services. Journeying with the surviving victim of mob justice as well as the family, needs to be part of the church's responsibility. The delay of these services by the church may result in a family crisis leading to retaliation or the use of further mob justice. That is how most genocide killings have developed on the African continent and it is the duty of the church, amongst others, to ensure that people are helped. It is one of the callings of the church to make peace between countries, peoples and nations. The letters of Paul make it very clear at the beginning where he always opens by speaking about the peace from God (e.g. Eph 1:1-2).

\section{The Christian fraternity within the context}

The Christian church through its leadership can organise itself to deal with and attempt to change this violent attitude in their respective communities. Pastors and preachers may start organising fellow Christians to meet and discuss these issues, and come up with ways indicating the importance of assisting our justice system, as well as turning people from taking the law into their own hands. More than that, it is the lives of other human beings, who were created in the image of God, whose lives are being terminated by these acts of violence. Robins (2009) is of the opinion that a restorative justice system should involve the offender taking responsibility, instead of making them a passive recipient of justice or punishment. He further argues that the justice must aim to bring the perpetrator to accept their wrongs, express regret and make a confession to the offended party as a way of integrating them back into society. It is evident that some criminals of this kind are arrested and placed in correctional services where they become the government's responsibility in South Africa, whereas the more integrated system would ensure that both the offender and the offended party are made to reconcile. This is a suggestion that the Christian leadership in the community can liaise with these parties and assist, locally, in making sure that the wrongs of the past cannot be used as grudges that will instil in peoples' minds for revenge.

\section{South African justice system}

There are many concerns that our justice system has not been protecting the law-abiding citizens against those who rob, steal, rape and commit other crimes against them. Without trying to make this the main focus of this study, it is important to also check by way of research how to assist our justice system to make it more effective in serving the nation, rather than taking the law into our own hands. In some residential areas and towns there are already 'policing forums' which assist to eradicate crime by co-operating with our justice system. This is one way of involving the entire society in helping the police to eradicate violence and crime. Besides policing forums, if every citizen is ready to cooperate and inform the police about crime, the work for both the citizens and the police will be easier. Many people only give information when they are victims themselves. Without condoning the laziness as well as bad practice from members of police services, the author thinks that co-operation between communities and policing forums can start dealing with crime more effectively than mob justice.

Our government should strengthen its hand in dealing with crime. I fully support Hamber and Lewis (1997) when arguing that the government needs to take measures to restore faith in the institutions of safety, security and justice, as well as to instil a renewed sense of safety and hope amongst the South African people. It does not feel safe, for instance, for the rape victim to see her rapist walking the streets the next day. This violence calls for the justice system to always ensure that they update old Acts on violence with new ones. By ensuring that the justice system puts extra effort into protecting every citizen they will bring back the lost faith in our justice system. Mofaledi's (2000) report to BBC News is also correct as he advocated that change will come if the administrators start 
adhering to and respecting the law. Perhaps it is important to also mention that the church has its prophetic role to play in giving the government direction in all matters, including the matters of our judiciary system. The Christian church has been very vocal against apartheid and it is my belief that the voices that played a role in bringing democracy into our country can still continue on issues of crime as well as encouraging the justice system to protect its citizens. The church should always stand for justice to prevail in the country. It is unfair for the church to leave the justice system solely in the hands of the politicians without any prophetic voice to give proper direction in accordance with God's word.

\section{The Bible on revenge}

Some innocent killings occur as revenge for previous wrongs. That is why, because of hatred, some people falsely accuse their personal enemies of wrongdoing for the sake of ridding themselves of them through mob violence. This is another form of revenge which the Bible is strongly against. The Bible says, in Romans 12:19, that people should not take revenge in any form, because God will exact revenge on their behalf. Without preaching, most states in the world respect this commandment, including South Africa. In a circular conception of this, any form of taking the law into one's own hands is a form of revenge. This is why in some countries, like South Africa, it is punishable by law to attempt to act as the justice system. God, who created people, did not allow any of them to take another life. This is what the church must continually teach in trying to eliminate the violence that is taking peoples' lives. This teaching must also be accompanied by the commandment that killing is a sin before God, the Creator of life. To make South Africa a peaceful place for all who live in it will require the church to emphasise to people the teaching of the spirit of caring for one another as this is one of the ways of attaining peace. Caring for one another implies, amongst other things, valuing one another's lives. This is what Wiersbe (2002) extensively wrote about in his book, Caring people. In other words, the church should start to be a church without walls, from which it reaches out to ordinary people in the streets for the sake of peace, and this must be prioritised. The spirit of revenge has and will always be against the African concept of $u b u n t u$ and this needs to be spread wherever the church receives an opportunity to be of influence, may it be at funerals, indabas and other traditional and formal gatherings.

\section{Teaching on imago Dei}

Without condoning or promoting cruelty against animals, I am in agreement with Fowler (1991:4) that one of the most distinguishing characteristics between human beings and other animals is that a human being is created in the image of God. It is, therefore, a serious mistake to treat other people as less than human by judging as well as punishing them. Although I understand the philosophical and theological arguments around the issue of man's (sic) image being dented in disobedience towards God (Anderson 1982:78), I also agree with Needleman, Bierman and Gould (1977:307) that man is God's image even in his natural state. My personal articulation is that though sin has inflicted damage to human beings being images of God, sin did not necessarily remove everything that gives us traces of God's image in every human being. This is not the main focus of the study, but the emphasis is that for us to respect life in every person we need to understand that God created man (sic), in His image, amongst other things. The relational image-ship of human beings cannot reduce other factors that make a human being the image of God. The imago Dei theology brings me to argue that the very same God who created human beings should be the judge, instead of human beings judging one another. The church has a role to play in teaching man's image-ship of God to people, which should also extend to issues of respecting the life of the individual, abstaining from being judgemental, abstaining from taking the power that only the rulers of the country were given, and so on. Within the imago Dei argument, it is relevant for the church to teach responsibility and accountability towards fellow human beings just as when Cain was expected to be his brother's keeper (Gn 4:9).

\section{The church as a peace builder}

The church is, amongst other responsibilities, a custodian of peace in God's world. The preaching and the manifestation of God's kingdom is usually viewed as peaceful, hence Jesus was also called the Prince of Peace (Is 9:6). It is undeniable that from the days of apartheid our black townships have been characterised by reactions which are usually accompanied by violence. It is, for me, time that the church should fight for the eradication of the violence which has ruled the South African people for decades. It is for this reason that ministers and pastors are expected to occupy dual roles as spiritual and secular leaders in our communities, particularly in the townships (Tshaka 2013:192). The kind of theological leadership we have in our townships determines the kind of society we want to become. This is why, although it is not the focus of this study, I concur with Tshaka (2013:182), in the quest of theological seminaries and universities, for the tools that will train leaders who will be relevant in their communities. Lederach (1998:37) echoes a similar sentiment when he focuses on the helpfulness of thinking about leadership in the population affected by conflict and violence. Lederach discusses an important means of bringing peace, through the use of a pyramid in which the church needs to identify the highly respected, influential and leading figures to be incorporated into the strategy of peace. Problem solving workshops, as well as raising awareness about the outcomes and negative consequences of violence, form the backbone of his strategy (Lederach 1998:41). Moreover, it is the duty of theologians and pastoral caregivers, within the violencetorn communities, to start instilling and reviving the spirit of ubuntu, which helps people to feel that they belong to one another. Finally, the collaboration between community leadership, the local policing forums and the police officers could be helpful in maintaining stability in our communities. This is a project the church leadership can initiate and ask for the involvement of other parties in the search for peace. 
I encourage that more churches emulate what the Saint Steven's Parish in Port Elizabeth did on 21 April 2013 when it assembled and even invited Jeff Radebe (Minister of Justice and Constitutional Development) to engage the residents on various issues including mob justice and fraud (Justice and Constitutional Development 2013). If similar engagements are arranged more regularly, the reduction of mob justice, as well as other violent practices in our townships, would be a real possibility.

\section{Conclusion}

The mob justice system is truly becoming a growing trend in South Africa and many people continually lose their lives through this practice. Although it is true that one of the biggest reasons for its growth is that people feel hopeless about the country's justice system, and their taking the law into their own hands worsens this circumstance. My opinion is that two wrong practices will never combine to make one right practice. Our country has become a place without safety where both the mob citizens and our police and security services are to blame. Thus, law abiding citizens are always fearful of their lives. The author is of the opinion that the church, as a custodian of peace and hope, cannot fold its arms and watch people endangered in this way. Theology has always been a good theology if it speaks to people in their immediate contexts. It is, therefore, the duty of the church to take a portion of responsibility to ensure that whilst the mob justice system is being discouraged and condemned, we also assist our justice system to uproot and eliminate crime.

\section{Acknowledgements Competing interests}

The author declares that he has no financial or personal relationships which may have inappropriately influenced him in writing this article.

\section{References}

AENS, 2014, 'Suspect killed in front of cops', Daily Sun, 15 July, 2014, p. 4.

Anderson, R.S., 1982, On being human - Essays in theological anthropology, William Eerdmans, Grand Rapids, MI.

Bearak, B., 2011, 'Watching the murder of an innocent man', The New 2011 York Times, 02 June, 2011, pp. 1-22.

Brodie, N., 2013, Guide: Understanding crime statistics in South Africa - What you need to know, viewed 04 September 2015, from https://africacheck.org

Casey, L.C.B., 2011, Review into the needs of families bereaved by homicide, pp. 1-71, viewed 16 October 2015, from http://www.justice.gov

Cook, N., 2013, South Africa: Politics, economy and us relations, pp. 1-28, Congressional Research Service, CRC Report, Report for Congress, Washington, DC.

Fanon, F., 1963, The wretched of the earth. The handbook for the black revolution that is changing the shape of the world, transl. C. Farrington, Grove Weidenfeld New York, NY

Fowler, S., 1991, The deceptive morality of power, IRS, Potchefstroom.

Goldbaum, C., 2014, 'Kin mourn boy killed in crossfire', Cape Times, 24 July, 2014, p. 6.
Hamber, B. \& Lewis, S., 1997, An overview of the consequences of violence and trauma in South Africa, Research for the Centre for the Study of Violence and Reconciliation, June 1997, Centre for the Study of Violence and Reconciliation, viewed 16 October 2015, from http://www.csvr.org.za

Hund, J., 2000, 'Witchcraft and accusations of witchcraft in South Africa: Ontological denial and the suppression of African justice', Comparative and International Law Journal of Southern Africa 33(3), 366-389.

Jazzie, 2014, Is necklacing returning in South Africa?, viewed 16 October 2015, from http://www.whatishappeninginsouthafrica.blogspot.co.za

Justice and Constitutional Development (JCD), 2013, 'Stand together for rights', Speech, Minister Jeff Radebe, Minister of Justice and Constitutional Development, on the occasion of the Conference on Mob Injustice, Fraud and Corruption Awareness with INGUQU and Saint Steven's Parish PE, 21 April 2013.

Kirsti, A. \& Dyer, M.D., 2005, 'Living through and surviving traumatic events', Medical Wellness Journal 2(2), 1-14, viewed 19 October 2015, from www. medicalwellnessaccociation.com

Lali, V., 2014, 'No mercy for cellphone robber', Daily Sun, 14 July, 2014, p. 4.

Lederach, J.P., 1998, Building peace. Sustainable reconciliation in divided societies, United States Institutes of Peace Press, Washington, DC.

Mabena, S., 2014, 'Steal and lose an eye', Daily Sun, 24 July, 2014, pp. 1-2.

Madienyane, D., 2013, The effects of vigilantism on the community of Diepsloot, MA research for the University of Witwatersrand, Graduate School of Public Development and Management, viewed 16 October 2015, from http://www. wiredspace.wits.ac.za

Maje, O., 2014, [No title], Taung Daily News, viewed 16 October 2015, from http:// www.taungdailynews.wordpress.com

Mathye, T., 2016, 'Police must restore public's faith in them', Daily Sun, 4 February, 2015, p. 18.

Minnaar, A., 2001, The new vigilantism in post-April 1994 South Africa: Crime prevention or expression of lawlessness, Institute of Human Rights and Criminal Justice Studies, Technikon SA.

Mofaledi, C.L.P., 2000, Is mob justice acceptable?, A news blog from BBC posted on 13 October 2000 at 09h29, viewed 16 October 2015, from http://www.news.bbc. co.uk

Mogotsi, T., 2014, 'Residents' fury', Daily Sun, 07 August, 2014, p. 5.

Mohale, D., 2014, 'My cop brother beat me up', Daily Sun, 30 July, 2014, p. 17.

Moobi, T., 2014, 'Petty thief saved in the nick of time', Daily Sun, 21 February, 2014, p. 8.

Ncayiyana, D.J., 2012, 'Euthanasia - No dignity in death in the absence of ethos of respect for human life', The South African Medical Journal 102(6), 334. PMID: 22668890.

Needleman, J., Bierman, A.K. \& Gould, J.A. (eds.), 1977, Religion for a new generation, Macmillan Publishers, New York, NY.

Robins, S., 2009, Restorative approaches to criminal justice in Africa: The case of Uganda, Monograph 161, Institute for Security Studies, pp. 57-84, n.p.

Saba, A., 2013, 'Vigilante terror: "Deep anger and resentment will spark mob justice",' City Press, 10 November, 2014, p. 1, 14:00, pp. 1-118.

SAPA, 2013, “'Useless” police blamed for vigilantism', City Press, 14 March, 2014, pp. $15-29$.

Shabangu, T., 2011, A comparative inquiry into the nature of violence and crime in Mozambique and South Africa, Idasa: An African Democracy Institute, n.p.

Sibiya, P., 2014, 'Thief locked down', Daily Sun, 07 July, 2014, p. 4.

Sihle, M., 2014, 'Metro cop held after hijack', Cape Times, 24 July, 2014, p. 5.

Siyavuya, M., 2014, 'Pupil, 17 killed by mob after burglary accusation', Cape Times, 24 July, 2014, p. 1.

Stavrou, V., 2011, Psychological effects of criminal and political violence on children, Centre for the Study of Violence and Reconciliation, viewed 16 October 2015, from http://www.csvr.org.za

Tshaka, R.S., 2013, 'Do our theological methodologies help us to deal with situations of violence in black communities, specifically afrophobia? So ganz anders. Fremdheit als theologisches und gesellschaftliches Phänomen', GBFE, Francke, Marburg.

Tshehla, M., 2014, 'We have no confidence in the cops', Daily Sun, 22 July, 2014, p. 10.

Wiersbe, W.W., 2002, Caring people: Learning to live with and help one another, Baker, Grand Rapids, MI.

Writer, J., 2014, 'Police officers assaulted a Somali leader', Cape Times, 24 July, 2014, p. 6.

York, G., 2014, Vigilante killings on the 'field of death' in South African township, viewed 16 July 2014, from http://www.theglobeandmail.com 